\title{
CHARACTERISTICS OF A BOTTOMLAND HARDWOOD FOREST AT ARCADIA LAKE, EDMOND, OKLAHOMA, WITH SPECIAL EMPHASIS ON GREEN ASH (FRAXINUS PENNSYL VANICA MARSHALL)
}

\author{
Chad B. King \\ Joseph A. Buck \\ Department of Biology \\ University of Central Oklahoma \\ Edmond, OK 73034 \\ Email: cking24@uco.edu
}

Keywords: emerald ash borer, Fraxinus pennsylvanica, flood

\begin{abstract}
We characterized the structure and tree species composition of bottomland hardwood forest at Arcadia Lake, Oklahoma County, Oklahoma. Additionally, we quantified the age structure of Fraxinus pennsylvanica Marshall (green ash) at the study site in order to establish a baseline dataset in the event that Agrilus planipennis (emerald ash borer) invades F. pennsylvanica stands in central Oklahoma. Three species, Salix nigra Marshall (black willow), F. pennsylvanica, and Populus deltoides W. Bartram ex Marshall (cottonwood) accounted for over $98 \%$ of importance values. These three species were also common in the understory. We found that $95 \%$ of $F$. pennsylvanica established following Arcadia Lake reaching pool conservation status in 1987. Arcadia Lake has experienced five sustained flooding events since 1995 that have likely played a role in regeneration at the study site. In particular, we showed that the 1995 event resulted in reduced radial growth in seedlings of $F$. pennsylvanica. Two biotic stressors appear to be influencing $F$. pennsylvanica overstory trees, Castor canadensis (American beaver) and Hylesinus spp. (ash bark beetle), which will likely enhance the establishment of $A$. planipennis at the study site. We recommend expanding the study of Fraxinus spp. forest stands in Oklahoma. Baseline data on Fraxinus species prior to an $A$. planipennis range expansion to central Oklahoma can enhance strategies for control and management of this invasive insect by identifying the traits of surviving ash following the invasion.
\end{abstract}

\section{INTRODUCTION}

Bottomland hardwood forests comprise approximately $10-14 \%$ of land cover in Oklahoma (Anderson and Masters 1992; Dooley 2017). Generally, this includes two broad classifications: Ulmus-Fraxinus-Populus (elm-ash-cottonwood) in central and eastern Oklahoma and Quercus-Liquidambar-

Taxodium (oak-sweetgum-cypress) in southeast Oklahoma. Bottomland hardwood forests in Oklahoma represent an important ecological component that exhibits high biological diversity in both aquatic and terrestrial habitats, and influence flood control ability and water quality (Brabander et al 1985; Anderson and Masters 1992; Rumble and Gobeille 1998).

Previous studies of bottomland hardwood forests along riparian corridors in Oklahoma have highlighted a commonality in terms of species composition but differences in species importance. Rice (1965) documented climax floodplain forest 
communities in north-central Oklahoma. He noted Ulmus americana L. (American elm) was the most common and dominant tree species across 10 counties. He also noted several other co-dominant species in these mature floodplain forests, including Celtis occidentalis L. (common hackberry), C. laevigata Willd. (sugarberry), Juglans nigra L. (black walnut), Carya illinoinensis (Wangenh.) K. Koch (pecan), Sapindus saponaria L. var. drummondii (Hook. \& Arn) L.D. Benson (western soapberry), and Fraxinus pennsylvanica Marshall (green ash). Hefley (1937) defined the climax floodplain community as Ulmus-Quercus (elm-oak) along the Canadian River in Cleveland County. Petranka and Holland (1980) documented bottomland hardwood forest composition at 13 sites along tributaries of the Washita River. They found that Salix nigra Marshall (black willow) and Celtis spp. were the most important overstory tree species at their study sites. Rice and Penfound (1956) found F. pennsylvanica to be the dominant overstory species at a site in Cleveland County, Oklahoma. Several species that were of higher importance in other studies (Rice 1965; Hefley 1937; Petranka and Holland 1980) were of minor importance at Rice and Penfound's (1956) site, possibly reflecting differences in stage of succession.

F. pennsylvanica was a component of all the previous studies in Oklahoma but varied in its importance. This species is a deciduous angiosperm in the Oleaceae (olive family). F. pennsylvanica is predominately found in bottomland forest associations, often with Salix nigra, Platanus occidentalis L. (American sycamore), Populus deltoides W. Bartram ex Marshall (cottonwood), Celtis spp., and Ulmus spp. (Hoagland 2000; Kennedy, Jr. 1990). According to the United States Forest Service Forest Inventory Analysis (Forest Inventory and Analysis 2018) there are an estimated 163.5 million individuals of Fraxinus spp. in Oklahoma greater than
$1 \mathrm{~cm} \mathrm{DBH} \mathrm{(diameter} \mathrm{at} \mathrm{breast} \mathrm{height).}$ While Fraxinus spp. only account for 3\% of stems $>1 \mathrm{~cm} \mathrm{DBH}$ in Oklahoma, these trees are under threat by the non-native emerald ash borer (Agrilus planipennis Fairmaire; Coleoptera: Buprestidae, EAB, Figure 1) as it expands its distribution westward in North America.

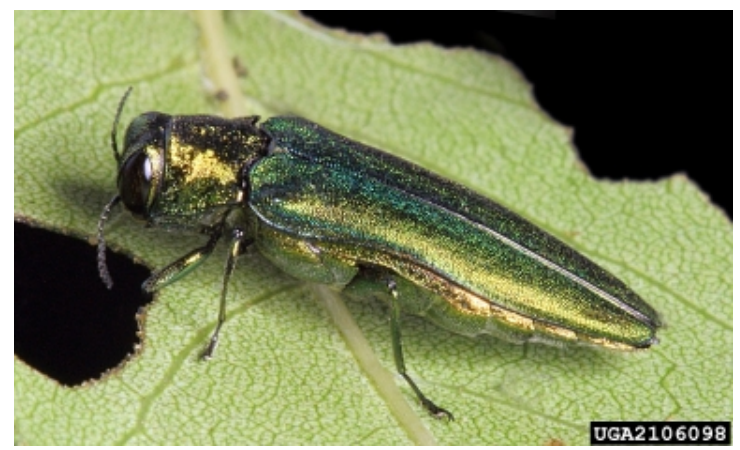

Figure 1 Adult emerald ash borer (Agrilus planipennis; David Cappaert, Bugwood.org https://www.insectimages.org/browse/deta il.cfm?imgnum $=2106098$ ). Creative

Commons License

(https://creativecommons.org/licenses/bync/3.0/us/legalcode). No modifications were made of the image.

Agrilus planipennis, native to Asia, was first detected in southeast Michigan in 2002 but is believed to have arrived sometime in the 1990s (Herms and McCullough 2014). Forests closest to the epicenter of invasion have experienced more than $99 \%$ ash mortality (Klooster et al. 2014). Since the initial detection, EAB has spread to 33 states and four Canadian provinces (Emerald Ash Borer Information Network 2018). In October 2016, EAB was detected in Delaware County, Oklahoma (Oklahoma Forestry Services, http://www.forestry.ok.gov/). This woodboring beetle feeds in galleries under the bark within the phloem and cambium of Fraxinus trees (Cappaert et al. 2005). The result of infestation is mortality due to girdling which eliminates the tree's ability to transport sugars and water. 
With this potential threat to Fraxinus in Oklahoma, there is an immediate need to study existing bottomland hardwood forests that contain Fraxinus. Baseline data on the existing structure and dynamics of bottomland hardwood forest communities, prior to an invasion by a non-native species, can provide invaluable information on approaches to control and manage the nonnative species and to identify traits of Fraxinus trees that survive, known as "lingering" ash (Knight et al. 2012; Koch et al. 2012).

The goal of our research is the establishment of a baseline dataset for a bottomland hardwood forest at Arcadia Lake, Oklahoma County, Oklahoma that has a high density of $F$. pennsylvanica. Research for this paper had three objectives: 1) record the tree species composition in both the overstory and understory, 2) quantify the characteristics of $F$. pennsylvanica structure and growth using standard forestry measurements and dendrochronology, and 3) relate patterns of Fraxinus establishment and bottomland hardwood forest structure to repeated flooding at Arcadia Lake. The results reported in this manuscript are part of a long-term study at Arcadia Lake to better understand bottomland hardwood forest succession and dynamics following the formation of the lake during the early 1980s.

\section{METHODS AND MATERIALS}

\section{Study Site}

Arcadia Lake (35 $38^{\prime} 54^{\prime \prime} \mathrm{N}, 97^{\circ} 21^{\prime} 47^{\prime \prime}$

$\mathrm{W})$ is a man-made lake located in northeast Oklahoma County, Oklahoma. The lake is found at the confluence of the Deep Fork River and Spring Creek. Formation of the earthen dam on the Deep Fork River began in 1980 with the conservation pool being filled by 1987. The United States Army Corps of Engineers maintains a lake surface elevation of $306.6 \mathrm{~m}(1006.0 \mathrm{ft})$ that covers $736.5 \mathrm{ha}(1820 \mathrm{ac})$. The lake is managed as a recreational area, drinking water source for the City of Edmond, and for flood control of the Deep Fork River (U.S. Army Corps of Engineers 2018).

The regional climate (Oklahoma Climate Division 5) is warm-temperate. Mean annual temperature $(1901-2017)$ is $15.7^{\circ} \mathrm{C}\left(60.2^{\circ} \mathrm{F}\right)$ with highest average monthly temperatures occurring in July-August $\left(27.7^{\circ} \mathrm{C}, 81.9^{\circ} \mathrm{F}\right.$; 1901-2017) and lowest average monthly temperatures occurring in DecemberJanuary $\left(3.3^{\circ} \mathrm{C}, 38.0^{\circ} \mathrm{F}\right.$; $\left.1901-2017\right)$. Precipitation during the year is bimodal, with the highest total monthly precipitation during May (12.9 cm, 5.10 in; 1901-2017) and September $(9.30 \mathrm{~cm}, 3.66$ in; 19012017) (National Oceanic and Atmospheric Administration 2018).

Soils adjacent to Arcadia Lake are dominated by Stephenville-Darsil-Newalla (3-8\% slope) fine sandy loam to sandy clay loam and Harrah (3-5\% slope) fine sandy loam. Soils at our specific study site at Arcadia Lake are Easpur loam (0-1\% slope). These soils are associated with bottomland/floodplain areas of Oklahoma County and have depths up to $203.2 \mathrm{~cm}$ (80 in) to bedrock (U.S. Department of Agriculture Web Soil Survey 2018).

Our study site at Arcadia Lake is located at the northwest section approximately $354 \mathrm{~m}$ from the inflow of Spring Creek into Arcadia Lake and is approximately 4.7 ha; the $F$. pennsylvanica stand studied for this paper covers 2.2 ha ( $47 \%$ of total study area).

\section{Fraxinus pennsylvanica stand structure and dendrochronology}

During Spring 2016, we began assigning individually identified tree tags to all $F$. pennsylvanica $\geq 5 \mathrm{~cm}$ DBH. Each tree was tagged with an individually assigned number that allows for continuous monitoring. Tags were nailed to trees at approximately 1.5$1.8 \mathrm{~m}$ height to minimize the chance of wildlife removing the tags. Waypoints were recorded using a handheld Garmin GPS for 
all tagged trees. We measured DBH (1.3 m above ground level) using a DBH tape measure $(\mathrm{cm})$ on all tagged trees. Tree height was estimated using a Nikon Forestry PRO Laser Rangefinder/Hypsometer.

We estimated the age structure of $F$. pennsylvanica by comparing increment cores (Speer 2010). Approximately every sixth tagged tree $(n=65)$ was cored at $30 \mathrm{~cm}$ above ground level using a $5 \mathrm{~mm}$ (diameter) Haglof increment borer. One to two cores $(n=83)$ were collected from each tree to get an estimate of tree age at coring height. Increment cores were stored in straws and returned to the TREE (TreeRing Ecology \& Environment) Lab at the University of Central Oklahoma for processing and analysis.

We mounted increment cores and sanded using progressively finer sandpaper (80-1200 grit) to visualize individual cells under a binocular microscope (Stokes and Smiley 1996). To determine age at coring height of $F$. pennsylvanica and radial growth dynamics, tree-ring widths were measured to the nearest $0.001 \mathrm{~mm}$ for each increment core using a Velmex TA Measuring System (Velmex, Inc., Bloomsfield, NY), a binocular microscope, and Measure J2X software (VoorTech Consulting, Holderness, NH). All tree-ring series were crossdated to assign calendar years to each tree-ring using the computer program COFECHA (Grissino-Mayer 2001; Holmes 1983) and graphical visualization.

We used ARSTAN (Cook and Holmes 1986) to create a stand-level standardized tree-ring index for F. pennsylvanica. The program allows for different detrending techniques that emphasize a signal of interest in tree-ring series. ARSTAN calculates a standardized tree-ring index by fitting a curve to each tree-ring series. A standardized tree-ring index for each tree is calculated by dividing each tree-ring width by the curve fit value. The stand-level standardized tree-ring index is the average of all individual standardized tree-ring indices. We applied a 10 -year cubic smoothing spline to create a standardized tree-ring index, given the relatively short tree-ring series, in order to understand the patterns of F. pennsylvanica growth at the study site.

\section{Bottomland forest structure}

To establish a baseline dataset in the event of EAB invasion, we categorized the bottomland hardwood forest structure and species composition at the study site. Four $150 \mathrm{~m}$ transects (oriented southeastnorthwest) were established within the 2.2 ha study area in an effort to understand bottomland forest regeneration. At $10 \mathrm{~m}$ intervals along each transect, a $1 \mathrm{~m}^{2}$ fixed area plot was established. All seedlings $(<1.3 \mathrm{~m}$ height $)$ and saplings $(>1.3 \mathrm{~m}$ height; DBH $<8 \mathrm{~cm}$ ) were counted to estimate stem density and identified to species. Four 0.04 ha fixed area circular plots $(n=16)$ were established along each transect to assess the overstory composition associated with F. pennsylvanica. Diameter at breast height was measured for all trees $>8 \mathrm{~cm} \mathrm{DBH}$, and each tree was identified to species. We calculated standard descriptive statistics for the overstory composition including tree density (stems/ha), basal area $\left(\mathrm{m}^{2} / \mathrm{ha}\right)$, relative density (species density/total tree density $\mathrm{x}$ 100), relative basal area (species basal area/total tree basal area $\mathrm{x} 100$ ), and importance (relative tree density + relative basal area) (Cottam and Curtis 1956; Curtis and McIntosh 1951).

\section{RESULTS}

\section{Fraxinus pennsylvanica stand structure and dendrochronology}

To date, a total of $404 \mathrm{~F}$. pennsylvanica trees have been individually tagged and measured at Arcadia Lake. The largest diameter was $35.1 \mathrm{~cm}$ (mean $=14.0 \mathrm{~cm}$, $\mathrm{SD} \pm$ 4.61). The tallest tree was $13.99 \mathrm{~m}$ $($ mean $=9.31 \mathrm{~m}, \mathrm{SD} \pm 2.16)($ Table 1$)$. 
Table 1 Summary statistics for F. pennsylvanica at Arcadia Lake, Oklahoma County, Oklahoma

\begin{tabular}{r|cccc} 
& N & Mean & SD & Range \\
\hline Diameter $(\mathrm{cm})$ & 404 & 14.0 & 4.61 & $7.00-35.1$ \\
Height $(\mathrm{m})$ & 404 & 9.31 & 2.16 & $2.20-13.9$ \\
Ring-width $(\mathrm{mm})$ & 83 & 3.55 & 1.67 & $1.71-6.92$ \\
Age (years) & 65 & 23.9 & 2.84 & $17.0-32.0$ \\
Tree-Ring Index $^{\mathrm{a}}$ & 83 & 0.99 & 0.15 & $0.92-1.00$
\end{tabular}

${ }^{a}$ Tree-ring index values correspond to the standardized chronology in Figure 4.

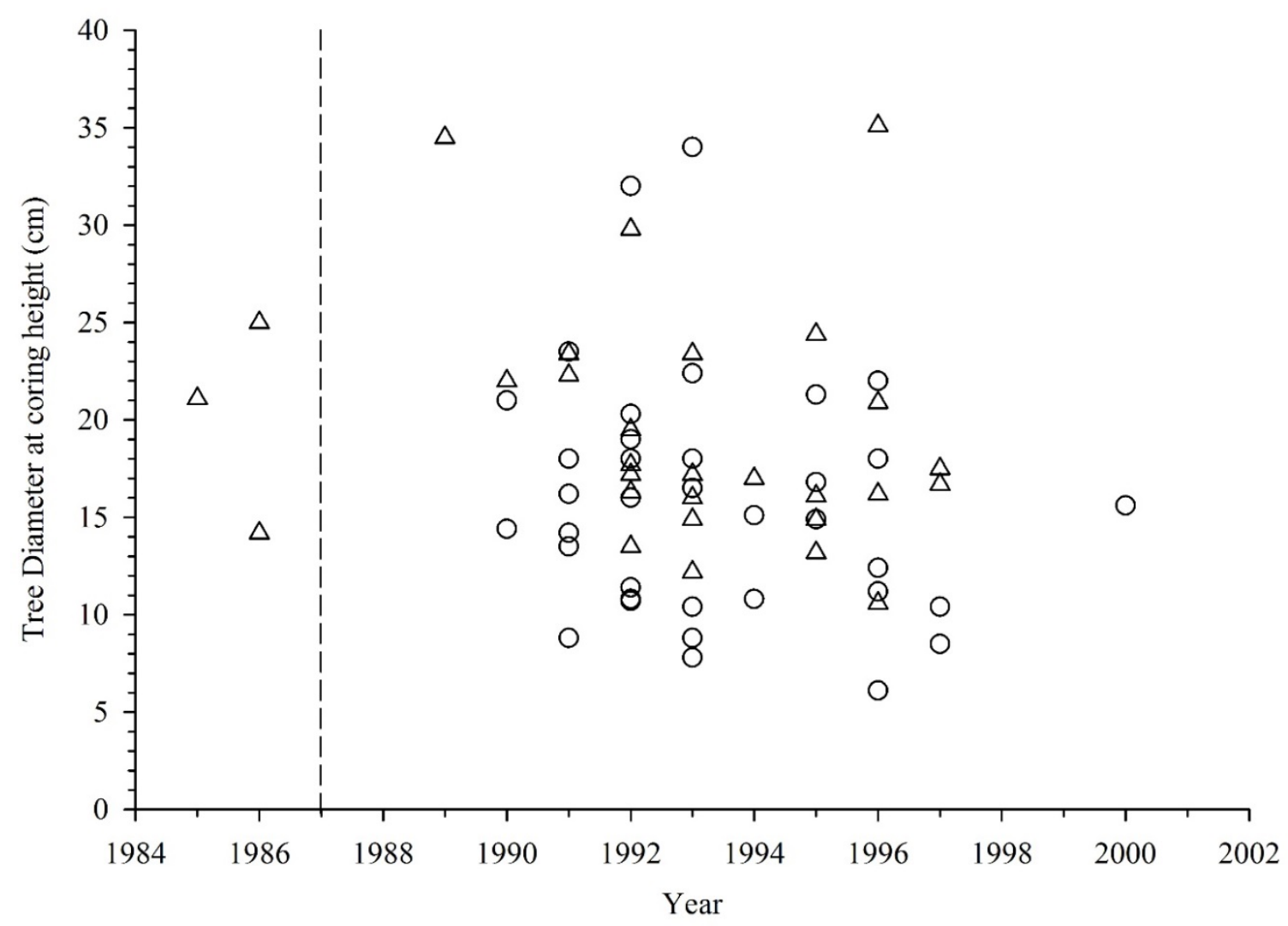

Figure 2 Actual (circles) and estimated pith dates (triangles) and tree diameter of green ash $(n=65)$ at Arcadia Lake, Oklahoma County, Oklahoma. Pith dates were estimated using the method indicated by Speer (2010) for trees in which coring missed the pith. Vertical dash line indicates the year (1987) that Arcadia Lake first reached conservation pool status $(306.6 \mathrm{~m}$; $1006 \mathrm{ft}$ ) following dam completion. 


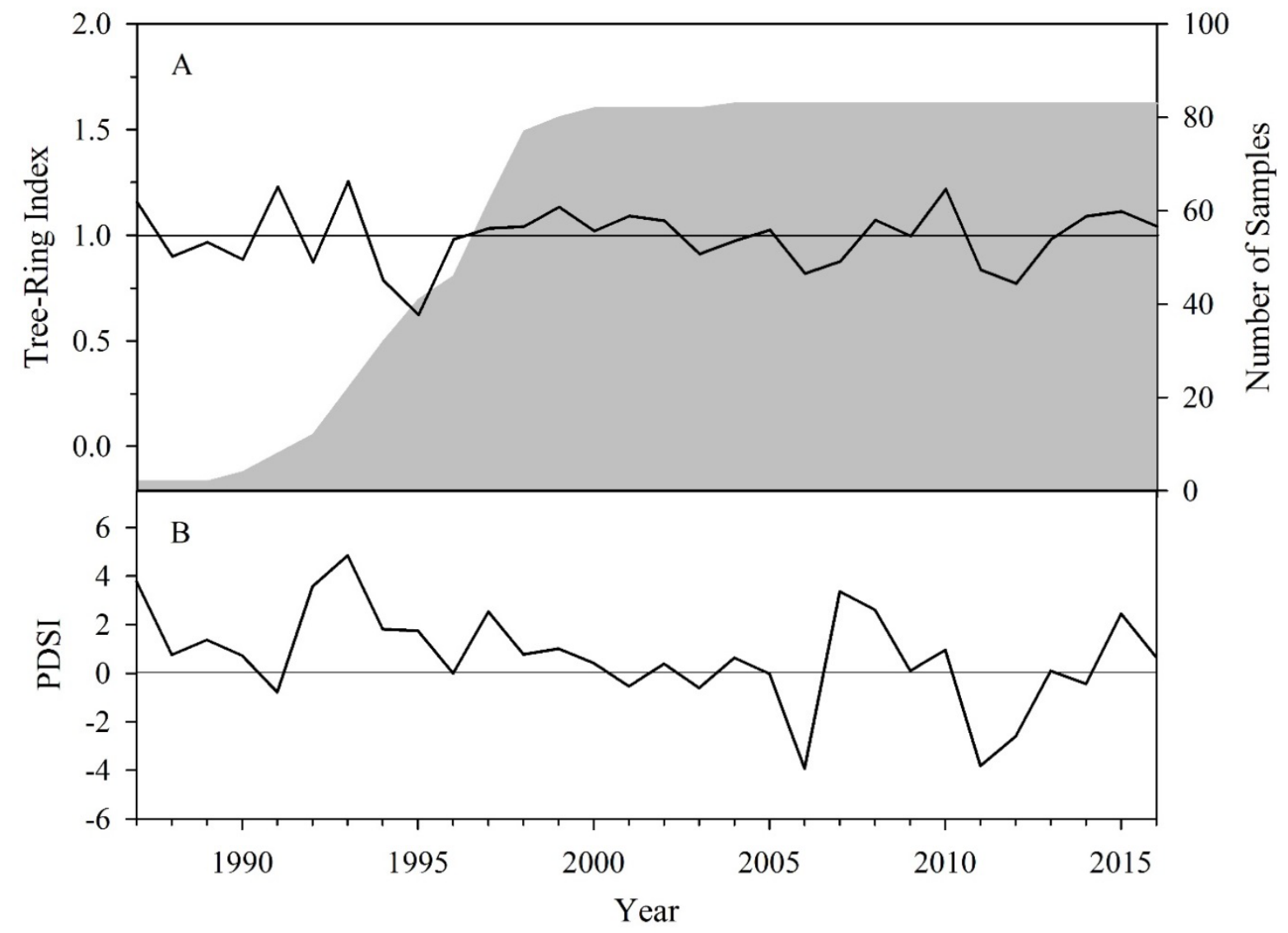

Figure 3 (A) Standardized tree-ring index of F. pennsylvanica at Arcadia Lake, Oklahoma County, Oklahoma (1987-2016). Tree-ring index is standardized using the computer program ARSTAN and methods outlined by Cook and Holmes (1986). The standardized tree-ring index has a mean $=1$ and is unitless. Index values $>1$ indicate above-average annual growth; index values $<1$ indicate below-average annual growth. Right y-axis is associated with the shaded area; left y-axis is associated with the standardized tree-ring index. (B) Annual Palmer Drought Severity Index (Palmer 1965) for Oklahoma Climate Division 5 (National Oceanic and Atmospheric Administration 2018). Values above zero indicate above-average annual moisture; values below zero indicate below-average annual moisture.

Eighty-three increment cores from 65 F. pennsylvanica trees were analyzed. The oldest F. pennsylvanica tree at the 2.2 ha site was 31 years old (estimated pith date $=$ 1985; Figure 2). Three trees pre-dated Arcadia Lake reaching conservation pool level (1987). Approximately 95\% of cored $F$. pennsylvanica trees established following Arcadia Lake formation in 1987 (see Figure 2).
F. pennsylvanica exhibited variable radial growth based on tree-ring measurements. Below-average growth was documented during the late 1980s and early 1990s (19871995; Figure 3). Following 1995, aboveaverage growth occurred in $52 \%$ of the years up to 2016. Below-average radial growth after 1995 corresponded with below-average Palmer Drought Severity Index for Oklahoma Climate Division 5 
(National Oceanic and Atmospheric Administration 2018).

\section{Bottomland forest structure}

Six species were documented in the overstory at the study site. Three species were identified in the understory (sapling/seedling) that were not present in the overstory (Table 2). Three species, Salix nigra, F. pennsylvanica, and Populus deltoides, had the highest importance values, accounting for over $98 \%$ of the importance values in this bottomland forest. F. pennsylvanica had the highest estimated overstory density (271.7 trees/ha) but a lower basal area $\left(6.654 \mathrm{~m}^{2} / \mathrm{ha}\right)$ compared to S. nigra and $P$. deltoides (see Table 2). S. nigra had the highest basal area $\left(10.73 \mathrm{~m}^{2} /\right.$ ha (see Table 2).

F. pennsylvanica had the highest seedling abundance with an estimated 1000 stems/ha. Ulmus spp. and Acer saccharinum L. (silver maple) were the second and third most common in the seedling stage, respectively (see Table 2). Two species documented in the overstory that lacked trees in the understory included Maclura pomifera (Raf.) C.K. Schneid. (Osage orange) and Gleditsia triacanthos L. (honey locust). F. pennsylvanica also had the highest estimated sapling density (250 stems/ha). $S$. nigra and $P$. deltoides were present in the seedling stage but lacking in the sapling stage in the understory.

\section{DISCUSSION}

We documented the characteristics of a bottomland hardwood forest at Arcadia Lake, Oklahoma County, Oklahoma. These data are a baseline in the event that EAB arrives in central Oklahoma. F. pennsylvanica was the second most important tree species in this forest and demonstrated regeneration in the understory (see Table 2). Other typical bottomland forest species were documented, including $S$. nigra and $P$. deltoides. Our findings were similar to those for other bottomland forests in the SouthCentral United States. At a site similar to ours in Texas, Rosiere et al. (2013) documented 15 tree species. We documented nine species at our study site in Oklahoma. Compared to Rosiere et al. (2013), several similar species were noted within our site, including Ulmus spp., G. triacanthos, F. pennsylvanica, Morus spp. (mulberry), and P. deltoides. Of note from Rosiere et al. (2013) was a very high importance value for $C$. laevigata, which was absent at our study site but can be found in adjacent upland areas around Arcadia Lake (King 2015). The importance value for F. pennsylvanica was much lower in Texas (Rosiere et al. 2013) and at a site in Cleveland and Calhoun counties, Arkansas (Lockhart et al. 2010), and it was a minor component in 13 southern Oklahoma bottomland forests (Petranka and Holland 1980).

An exception to the lower $F$. pennsylvanica component in the previous studies is the $F$. pennsylvanica-dominant forest near Norman, Oklahoma (Rice and Penfound 1956). Similar to our results, Rice and Penfound documented low density of $P$. deltoides in the understory even though this species was one of the most important species in the overstory. Possible explanations for the differences in species composition and $F$. pennsylvanica densities may be differences in hydrology and age of forest stands. The Arkansas study site (Lockhart et al. 2010) was along a braided stream, and the Texas study site (Rosiere et al. 2013) was along the Bosque River. Our study site, while located near Spring Creek, was situated along the edge of Arcadia Lake. Lockhart et al. (2010) suggested that their bottomland forest was old-growth which is in contrast to our study site, where very few F. pennsylvanica had pith dates prior to 1990 . 


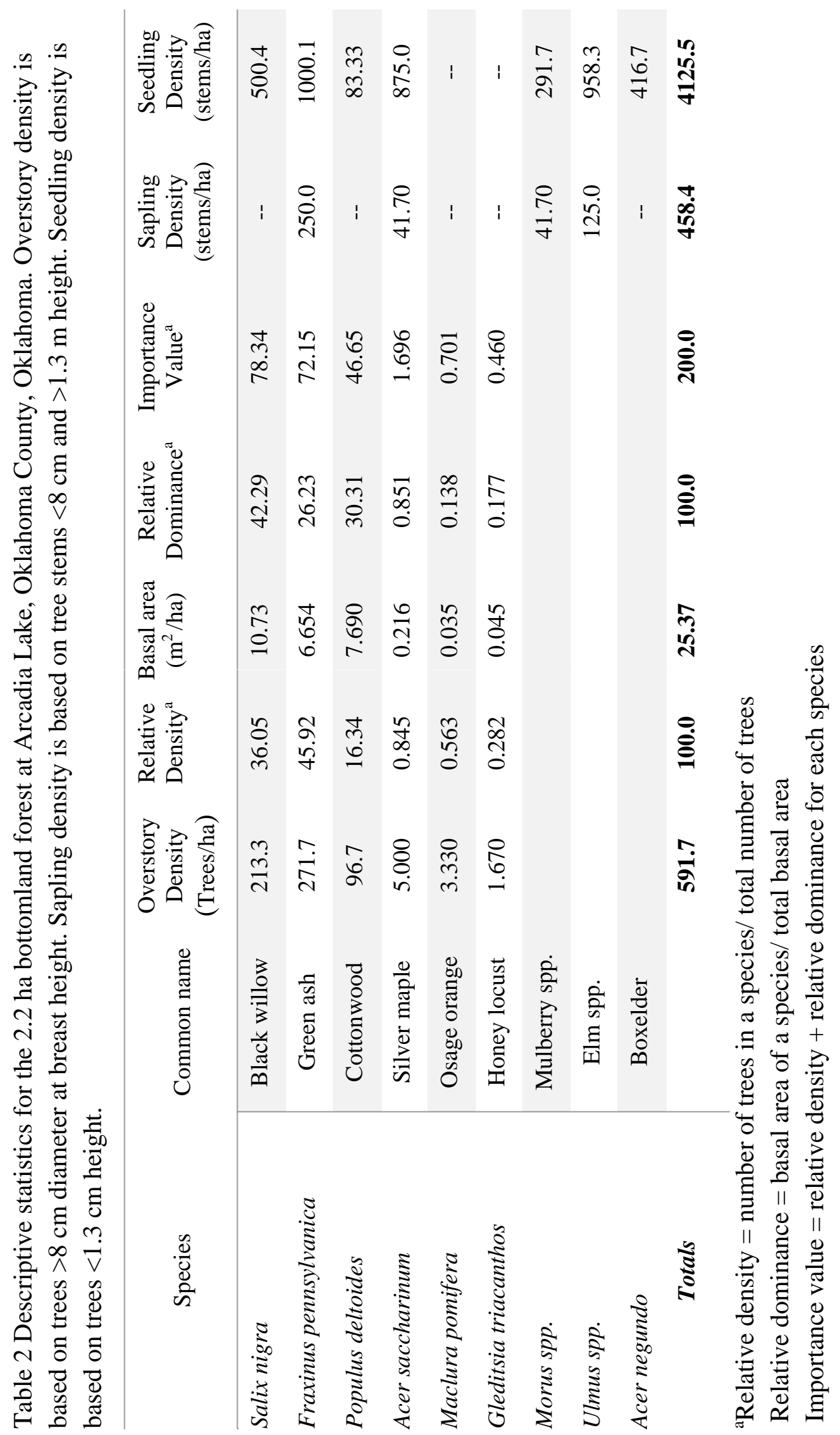



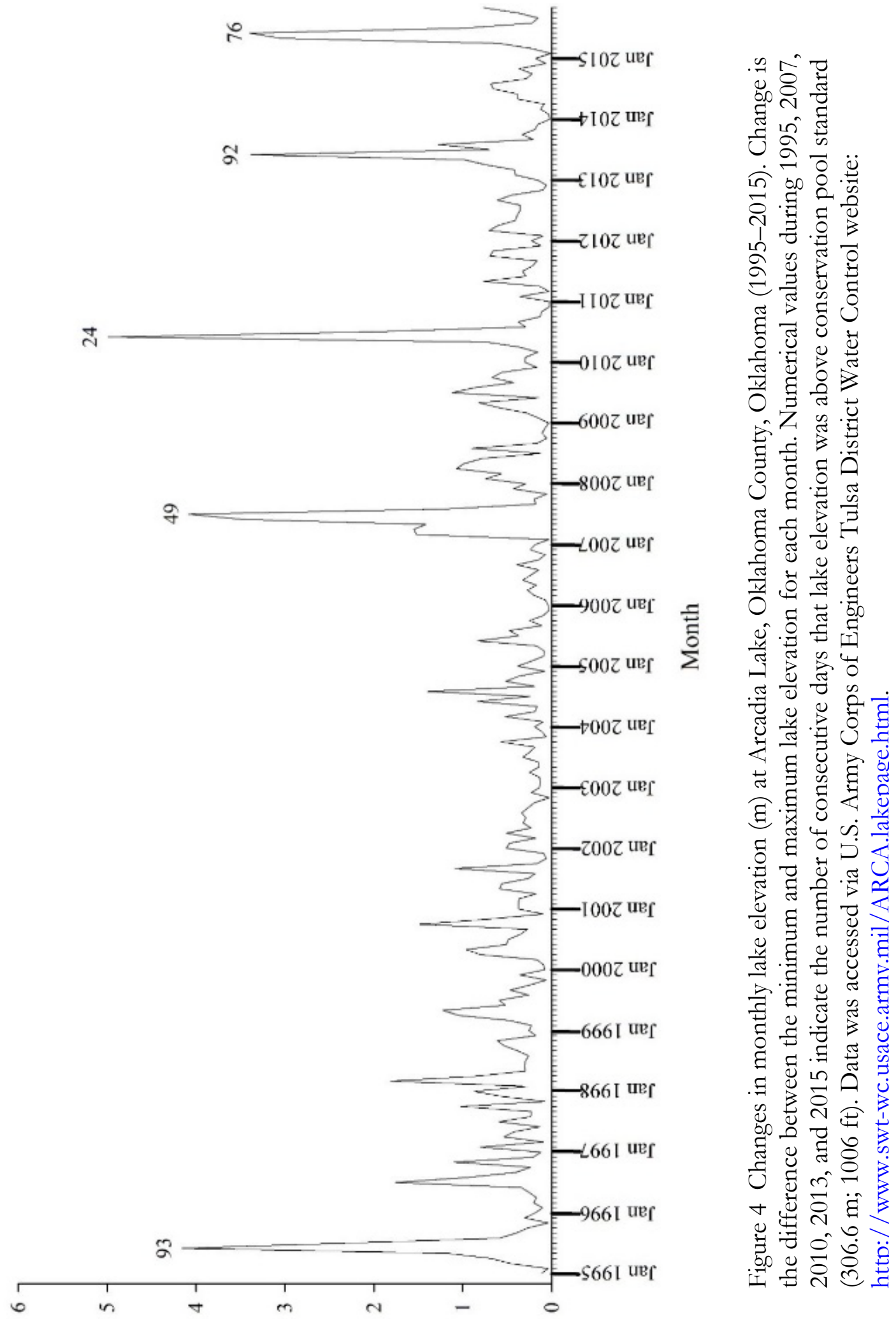

(ய) บо!ฺ๋ 


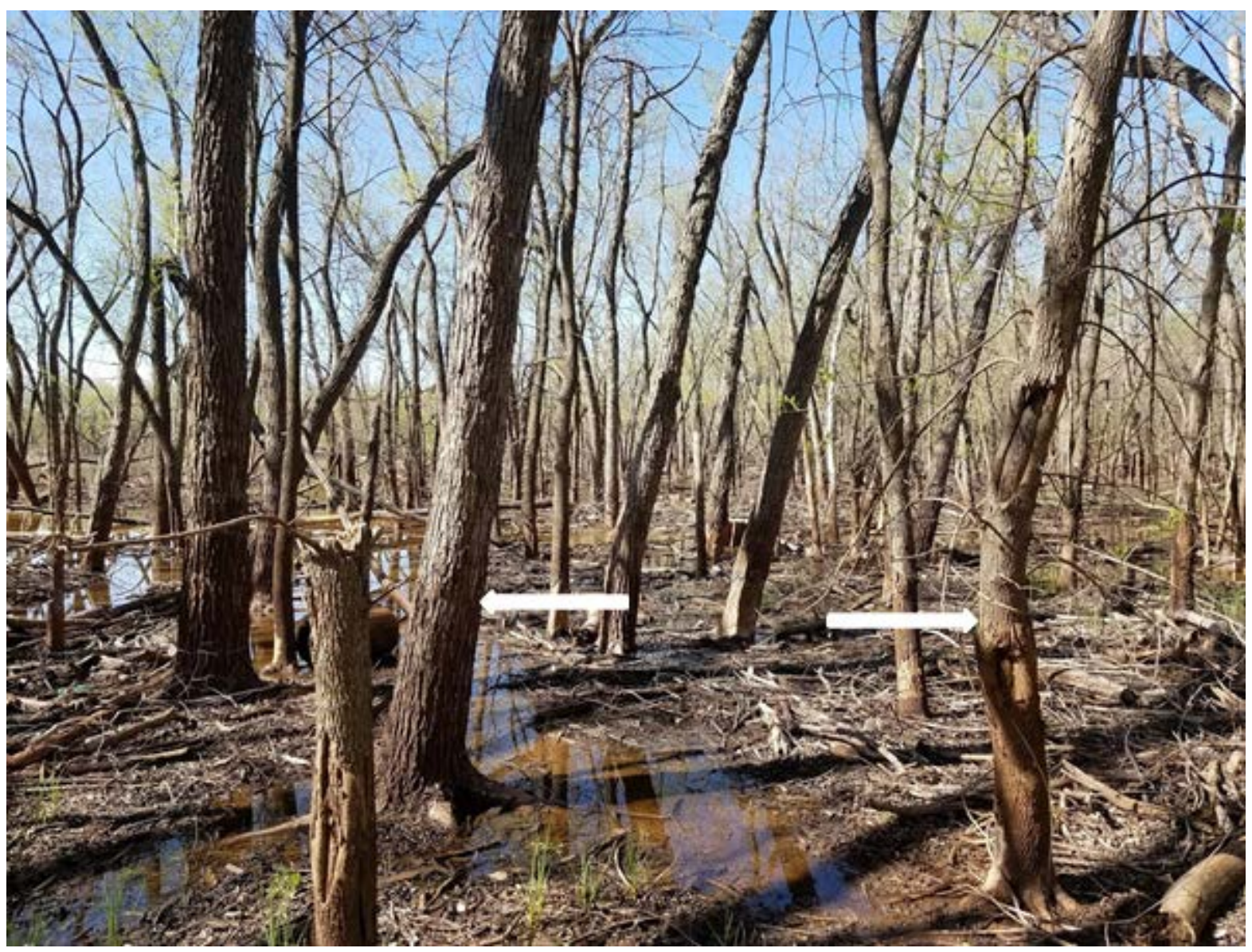

Figure 5 Image of the bottomland forest study site along the northwest edge of Arcadia Lake, Oklahoma County, Oklahoma. Photograph was taken April 27, 2018, when lake elevation was 1.1 feet $(0.33 \mathrm{~m})$ above conservation pool standard $(306.6 \mathrm{~m}$; $1006 \mathrm{ft})$. The lake edge can be seen in the left-center of the image. Previous flooding height is documented with white arrows approximately $1 \mathrm{~m}$ above ground level. Photo by Chad B. King.

Rice (1965) described and documented bottomland forest communities in northcentral Oklahoma. He described 10 different bottomland forest communities; three were in Oklahoma County, including U. americana, U. americana-C. laevigata, and $U$. americana-F. pennsylvanica community types. These were named based on the two species that had importance values $>75$. Our study site lacked overstory Ulmus species. While Ulmus was identified in the understory, S. nigra and F. pennsylvanica were the dominant overstory species (see Table 2). Ulmus species are present around Arcadia Lake (U. americana, Ulmus rubra Muhl.) but are most often associated with upland areas (King 2015).

One important factor that may be playing a role in the succession of this bottomland hardwood forest is repeated, sustained flooding. Arcadia Lake was formed by damming the flow of the Deep Fork River and, to a lesser degree, Spring Creek. The U.S. Army Corps of Engineers 
maintain a conservation pool at $306.6 \mathrm{~m}$ $(1006 \mathrm{ft})$ elevation. Precipitation events increase Arcadia Lake levels and cause flooding at our study site. Five pronounced events have occurred since the U.S. Army Corps of Engineers began recording daily lake levels in 1994 (U.S. Army Corps of Engineers 2018). Figure 4 highlights events during 1995, 2007, 2010, 2013, and 2015 that resulted in multiple, consecutive days of lake elevations $>306.6 \mathrm{~m}$. These flood events result in several days of standing water that often inundate seedlings and saplings (Figure 5). Lake elevation data also demonstrate that every year between 1995 and 2015 had a period of flooding at the study site. These repeated flooding events maintain bare, moist soil (Scott et al. 1996) that likely contributed to the establishment of F. pennsylvanica (see Figure 2) and other bottomland species. We demonstrate that 95\% of cored F. pennsylvanica established after the lake reached conservation pool status in 1987 (see Figure 2) and suggest that increased moisture availability promoted the establishment of F. pennsylvanica and other bottomland tree species.

We also show that approximately $72 \%$ of the cored $F$. pennsylvanica trees established prior to the 1995 flood year (see Figure 2 and Figure 4) and ranged in age from 1-10 years old at that time. From April 18, 1995, through July 19, 1995, Arcadia Lake elevation was $>306.9 \mathrm{~m}(1007 \mathrm{ft})$ and reached a peak of $311.7 \mathrm{~m}$ (1022.8 ft) on June 12, 1995. This 93-day flooding event was due to $51.5 \mathrm{~cm}$ (20.29 in) of rainfall from April through July, 1995. It is likely that most of the 1-4 year old F. pennsylvanica trees were completely inundated with water for several days. This is emphasized by the narrow 1995 tree-ring (see Figure 3) that was formed in the seedlings and saplings during that year. In contrast, dendrochronological work at other study sites near our study site demonstrated wider than average growth rings for 1995 (King and Cheek 2015; King unpubl. data). This suggests a reduced radial growth rate that is likely attributed to prolonged inundation and reduced photosynthesis during the 1995 growing season. Despite reduced growth rates, these green ash trees survived the 1995 flood. Hosner (1958) demonstrated that F. pennsylvanica and $S$. nigra seedlings could survive up to 16 days while inundated. Krinard and Johnson (1981) documented $>50 \%$ survival of $F$. pennsylvanica and P. deltoides seedlings following flooding events during the 1970s along the Mississippi River. In studies that encompassed several species found at our site, Loucks (1971) and Loucks and Keen (1973) found 100\% survival of

$F$. pennsylvanica seedlings after four weeks of submersion; A. negundo L. (boxelder) had increased mortality after the third week; $P$. deltoides had increased mortality in the fourth week of submersion; and A. saccharinum had $100 \%$ survival after four weeks of submersion. This mirrors the seedling density data in this study (see Table 2) which show higher densities for these same species that are able to survive prolonged submersion. The four highest estimated seedling densities were F. pennsylvanica, Ulmus spp., A. saccharinum, and $A$. negundo. The high frequency of flooding at Arcadia Lake (see Figure 4) likely plays a role in the regeneration of these flood tolerant species while reducing the survival of less flood tolerant species. All of the species documented in our study are classified as intermediate to very tolerant of flooding as mature trees and able to survive flooding or saturated soils up to a minimum of 30 days (Clatterbuck 2005). These periodic flooding events, particularly during the growing season (see Figure 4) are likely influencing regeneration that favors flood tolerant species and maintains the existing species composition.

In addition to flood tolerance, we have found that $F$. pennsylvanica encounters biotic stressors that may make it more prone to 
EAB attack at Arcadia Lake. American beaver (Castor canadensis) are active and have girdled many F. pennsylvanica, S. nigra, and $P$. deltoides trees around Arcadia Lake (Figure 6A). We have begun documenting beaver damage and have currently found that $30 \%$ of $F$. pennsylvanica trees have some type of beaver damage (King unpubl. data). Native ash bark beetles (Hylesinus spp; Coleoptera: Curculionidae) are also present at Arcadia Lake (Figure 6B). These insects are phloem-feeders and attack recently stressed trees impacted by mechanical damage or disease (U.S. Department of Agriculture Forest Service 1985). These biotic stressors have likely increased the probability for the establishment of a viable EAB population in central Oklahoma.
With the detection of EAB in Delaware County, Oklahoma in 2016 there is an increased likelihood of the continued westward expansion of this non-native beetle to Oklahoma County. Modelled short range dispersal of EAB is on average $20 \mathrm{~km}$ per year (Prasad et al. 2010) but long range dispersal is facilitated by humans, often via firewood and wood products that contain undetected EAB. Arcadia Lake has camping areas and does not currently restrict firewood transport (Leon Mixer, City of Edmond Arcadia Lake Supervisor, pers. comm. 4/13/2018). This, and the aforementioned biotic stressors, potentially increase the risk for $\mathrm{EAB}$ introduction to the Arcadia Lake area.
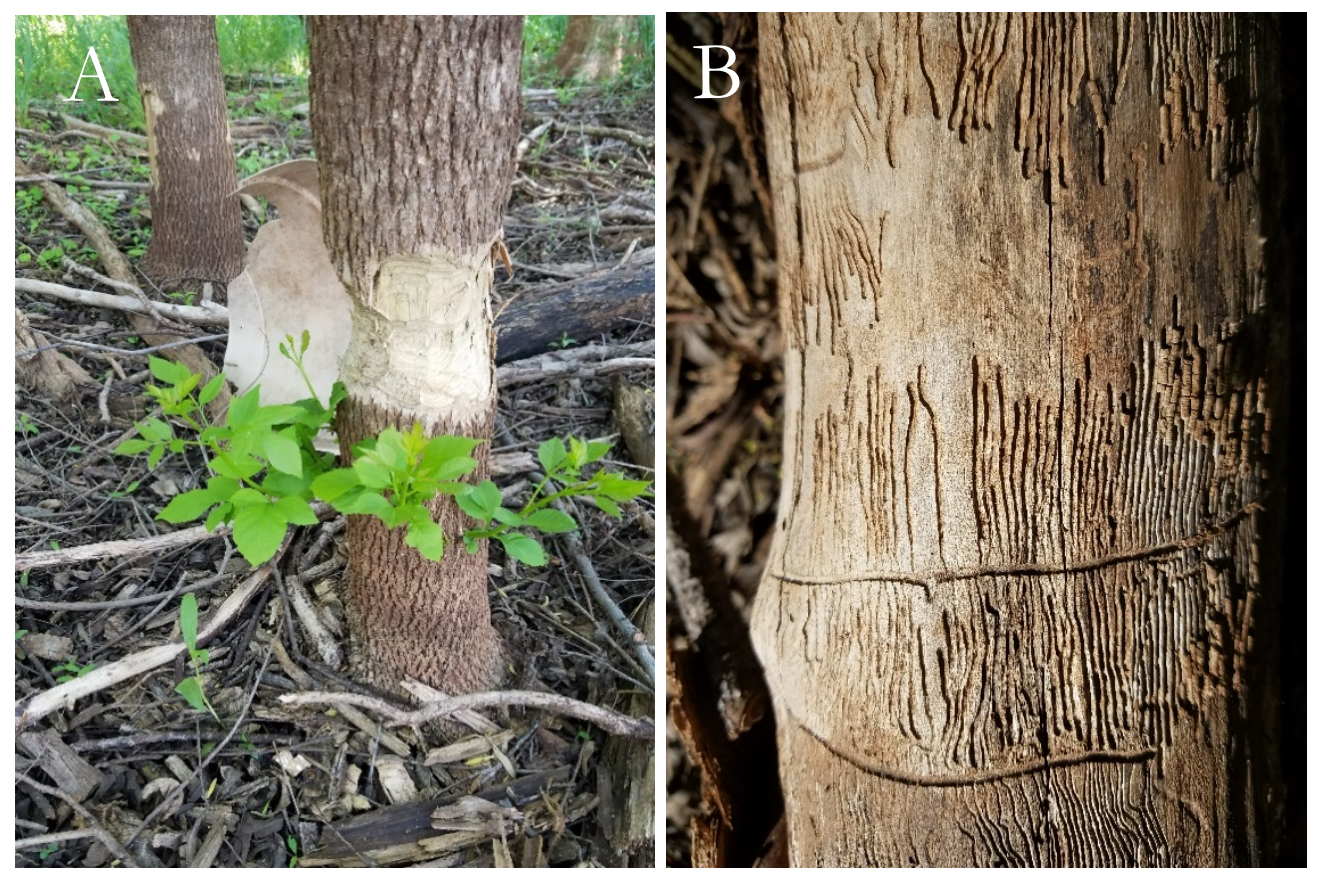

Figure 6 Two examples of biotic stressors on green ash at Arcadia Lake, Oklahoma County, Oklahoma. (A) American beaver activity that nearly girdled this green ash and subsequent sprouting by the green ash. (B) Ash bark beetle (Hylesinus sp.) galleries located under the bark of a dead green ash. Photos by Chad B. King. 


\section{CONCLUSIONS}

We documented the characteristics of a bottomland hardwood forest at Arcadia Lake, Oklahoma County, Oklahoma with an emphasis on the current age structure of $F$. pennsylvanica. The three dominant species in the overstory were $S$. nigra, $F$. pennsylvanica, and P. deltoides. Regeneration of the three overstory species was occurring in this bottomland forest. Frequent flooding of Arcadia Lake since 1995 has sustained this bottomland forest and has likely restricted the establishment of more flood intolerant tree species. The high density of F. pennsylvanica and additional biotic stressors at this study site may set the stage for the invasion of $\mathrm{EAB}$ in the future. We recommend foresters, scientists, and the public document the locations of $F$. pennsylvanica stands in Oklahoma for further monitoring of $\mathrm{EAB}$ infestation.

\section{ACKNOWLEDGMENTS}

We thank Justin Cheek and Kaitlyn Dunbar for their assistance in collecting increment cores at Arcadia Lake and Nayyer Ahrabi and MacKenzie Endebrock for their assistance in tagging green ash. We graciously thank the City of Edmond for permission to sample and study the bottomland forest at Arcadia Lake. Incredibly helpful comments and suggestions were made by three anonymous reviewers. Funding for portions of this project was awarded from the University of Central Oklahoma Office of Research and Grants.

\section{LITERATURE CITED}

Anderson, S.A. and R.E. Masters. 1992. Riparian forest buffers. Fact sheet no. 5034. Stillwater (OK): Oklahoma State University Cooperative Extension Service.
Brabander, J.J., R.E. Masters, and R.M. Short. 1985. Bottomland Hardwoods of Eastern Oklahoma: A Special Study of Their Status, Trends, and V alues. Oklahoma Department of Wildlife Conservation.

Cappaert, D., D.G. McCullough, T.M. Poland, and N.W. Siegert. 2005. Emerald ash borer in North America: a research and regulatory challenge. American Entomologist 51:152-165.

Clatterbuck, W.K. 2005. SP656 Shade and flood tolerance of trees. University of Tennessee Agricultural Extension Service. SP656-15M-9/05. R12-4910051-001-06 06-0066, http://trace.tennessee.edu/utk agexfor es/60.

Cook E.R. and R.L. Holmes. 1986. Users manual for program ARSTAN. In: Holmes, R.L., R.K. Adams, and H.C. Fritts, eds. Tree-Ring Chronologies of Western North America: California, Eastern Oregon and Northern Great Basin with Procedures Used in the Chronology Development Work Including Users Manuals for Computer Programs COFECHA and ARSTAN.

Cottam, G. and J.T. Curtis. 1956. The use of distance measures in phytosociological sampling. Ecology 37:451-460.

Curtis, J.T. and R.P. McIntosh. 1951. An upland forest continuum in the prairieforest border region of Wisconsin. Ecology 32:476-496.

Dooley, K. 2017. Forests of Oklahoma, 2015. Resource update FS-126. Asheville (NC): U.S. Department of Agriculture Forest Service, Southern Research Station.

Emerald Ash Borer Information Network. 2018. http://www.emeraldashborer.info (10 July 2018).

Forest Inventory and Analysis. Design and Analysis Toolkit for Inventory and Monitoring Web Application, Version May 24, 2018 r6082. St. Paul (MN): U.S. Department of Agriculture, Forest Service, Northern Research Station. 
https://www.fs.fed.us/emc/rig/DATI M/index.shtml (9 July 2018).

Grissino-Mayer, H.D. 2001. Evaluating crossdating accuracy: A manual and tutorial for the computer program COFECHA. Tree-Ring Research 57:205221.

Hefley, H.M. 1937. Ecological studies on the Canadian river floodplain in Cleveland County, Oklahoma. Ecological Monographs 7:345-402.

Herms, D.A. and D.G. McCullough. 2014. Emerald ash borer invasion of North America: History, biology, ecology, impacts, and management. Annual Review of Entomology 59:13-30.

Hoagland, B. 2000. The vegetation of Oklahoma: A classification for landscape mapping and conservation planning. Southwestern Naturalist 45:385420.

Holmes, R.L. 1983. Computer assisted quality control in tree-ring dating and measurement. Tree-Ring Bulletin 43:6978.

Hosner, J.F. 1958. The effects of complete inundation upon seedlings of six bottomland tree species. Ecology 39:371373.

Kennedy, Jr. H.E. 1990. Fraxinus pennsylvanica Marsh. In: Burns, R.M. and B.H. Honkala, tech. coords. Silvics of North America 2: Hardwoods. Agriculture Handbook 654. Washington (DC): U.S. Department of Agriculture, Forest Service.

King, C.B. 2015. Forest structure and fire history at Lake Arcadia, Oklahoma County, Oklahoma. Oklahoma Native Plant Record 15:19-30.

King, C.B. and J. Cheek. 2015. Dendroecology, forest composition, and land-use history of a suburban Cross Timbers forest in central Oklahoma. Urban Naturalist 6:1-19.

Klooster, W.S., D.A. Herms, K.S. Knight, C.P. Herms, D.G. McCullough, A. Smith, K.J.K. Gandhi, and J. Cardina.
2014. Ash (Fraxinus spp.) mortality, regeneration, and seed bank dynamics in mixed hardwood forests following invasion by emerald ash borer (Agrilus planipennis). Biological Invasions 16:859873.

Knight, K.S., D. Herms, R. Plumb, E. Sawyer, D. Spalink, E. Pisarczyk, B. Wiggin, R. Kappler, E. Ziegler, and K. Menard. 2012. Dynamics of suriving ash (Fraxinus spp.) populations in areas long infested by emerald ash borer (Agrilus planipennis). In: Sniezko, R.A., A.D. Yanchuck, J.T. Kliejunas, K.M. Palmieri, J.M. Alexander, and S.J. Frankel, tech. coords. Proceedings of the Fourth International Workshop on the Genetics of Host-Parasite Interactions in Forestry: Disease and Insect Resistance in Forest Trees. Gen. Tech. Rep. PSW-GTR-240. Albany (CA): Pacific Southwest Research Station, Forest Service, U.S. Department of Agriculture.

Koch, J.L., D.W. Carey, K.S. Knight, T. Poland, D.A. Herms, and M.E. Mason. 2012. Breeding strategies for the development of emerald ash borer resistant North American ash. In: Sniezko, R.A., A.D. Yanchuck, J.T. Kliejunas, K.M. Palmieri, J.M. Alexander, and S.J. Frankel, tech. coords. Proceedings of the Fourth International Workshop on the Genetics of Host-Parasite Interactions in Forestry: Disease and Insect Resistance in Forest Trees. Gen. Tech. Rep. PSW-GTR-240. Albany (CA): Pacific Southwest Research Station, Forest Service, U.S. Department of Agriculture.

Krinard, R.M. and R.L. Johnson. 1981. Flooding, beavers, and hardwood seedling survival. Southern Forest Experiment Station Report SO-270. New Orleans (LA): Southern Forest Experiment Station, Forest Service, U.S. Department of Agriculture.

Lockhart, B.R., J.M. Guldin, and T. Foti. 2010. Tree species composition and 
structure in an old bottomland hardwood forest in south-central Arkansas. Castanea 75:315-329.

Loucks, W.L. 1971. Submersion tolerance of selected seedling trees [Master's thesis]. Manhattan (KS): Kansas State University.

Loucks, W.L. and R.A. Keen. 1973. Submersion tolerance of selected seedling trees. Journal of Forestry 8:496497.

National Oceanic and Atmospheric Administration (NOAA) National Centers for Environmental Information. Climate at a Glance: Divisional Time Series, published April 2018. http://www.ncdc.noaa.gov/cag// (10 May 2018).

Oklahoma Forestry Services. 2018. Emerald Ash Borer. http://www.forestry.ok.gov/eab (10 July 2018).

Palmer, W.C. 1965. Meteorological drought. Research paper no. 45. Washington (DC): Weather Bureau, U.S. Department of Commerce.

Petranka, J.W. and R. Holland. 1980. A quantitative analysis of bottomland communities in south-central Oklahoma. Southwestern Naturalist 25:207-213.

Prasad, A.M., L.R. Iverson, M.P. Peters, J.M. Bossenbroek, S.N. Matthews, T.D. Sydnor, and M.W. Schwartz. 2010. Modeling the invasive emerald ash borer risk of spread using a spatially explicit cellular model. Landscape Ecology 25:353369.
Rice, E.L. 1965. Bottomland forests of north-central Oklahoma. Ecology 46:708714.

Rice, E.L. and W.T. Penfound. 1956. Composition of a green ash forest near Norman, Oklahoma. Southwestern Naturalist 1:145-147.

Rosiere, R.E., A.D. Nelson, and L.P. Cowley. 2013. Composition and structure of a mixed-hardwood bottomland forest in the West Cross Timbers of North-Central Texas. Southwestern Naturalist 58:81-90.

Scott, M.L., J.M. Friedman, and G.T. Auble. 1996. Fluvial process and the establishment of bottomland trees. Geomorphology 14:327-339.

Speer, J.H. 2010. Fundamentals of Tree-Ring Research. Tucson (AZ): University of Arizona Press.

Stokes, M.A. and T.L. Smiley. 1996. An Introduction to Tree-Ring Dating. Tucson (AZ): University of Arizona Press.

United States Army Corps of Engineers, Tulsa District. Arcadia Lake. http://www.swt.usace.army.mil/Locatio ns/Tulsa-DistrictLakes/Oklahoma/Arcadia-Lake/ (15 April 2018).

United States Department of Agriculture, Forest Service. 1985. Insects of eastern forests. Miscellaneous Publication 1426. Washington (DC): U.S. Department of Agriculture, Forest Service.

United States Department of Agriculture. 2018. Natural Resources Conservation Service Web Soil Survey. https://websoilsurvey.sc.egov.usda.gov (10 May 2018). 